\title{
School injuries and their prevention from the present perspective
}

Authors' Contribution: A Study Design B Data Collection

C Statistical Analysis D Data Interpretation E Manuscript Preparation F Literature Search G Funds Collection

\author{
Václav Beranek ${ }^{1,2}$ ABCDEFG, Petr Stastny ${ }^{1}$ ACDE, Vit Novacek ${ }^{3}$ CDE \\ ${ }^{1}$ Department of Sport Games, Faculty of Physical Education and Sport, \\ Charles University, Prague, Czech Republic \\ 2 Department of Rescue Services, Diagnostic Fields and Public Health, \\ Faculty of Health Care Studies, University of West Bohemia, Pilsen, Czech Republic \\ ${ }^{3}$ Biomechanical Human Body Models, New Technologies - Research Centre, \\ University of West Bohemia, Pilsen, Czech Republic
}

\section{abstract}

Background: Injuries are considered worldwide to be the most significant health problem, especially in childhood. In the Czech Republic, injuries are the most common cause of death among children and young adults. The aim of the study was to provide more insight in school accidents in the Czech Republic from 2008 to 2018 and to estimate future trends.

Material and methods: Annual reports of the Czech School Inspectorate (CSI) from 2007 to 2017 were the main sources of data.

Results: A high number of injuries occur in the school environment, especially at the primary level. In the Czech Republic, there has been a trend of rising numbers in reported school injuries over the last three years, from 33,000 in 2008 to 46,000 in 2018. Over the last 5 years, the number of reported accidents has increased by 1,000 per year. The most injuries occur in primary schools, within the subject Physical Education.

Conclusions: There are many activities which focus on the prevention of child injuries, the incidence of which has improved in recent years. Experience shows that when prevention programs include innovations and interesting presentation methods, they are successful.

Key words: injuries, cause of death, children, school, prevention.

\section{article details}

Article statistics:

Full-text PDF:

Copyright Indexation:

Funding:

Conflict of interests: Corresponding author: Open Access License:

Word count: 2,970; Tables: 3; Figures: 3; References: 20

Received: October 2020; Accepted: January 2021; Published: March 2021

http://www.balticsportscience.com

(c) Gdansk University of Physical Education and Sport, Poland

Celdes, Clarivate Analytics Emerging Sources Citation Index (ESCI), CNKI Scholar (China National Knowledge Infrastructure), CNPIEC, DOAJ, EBSCO - Central \& Eastern European Academic Source, EBSCO - SPORTDiscus, EBSCO Discovery Service, Google Scholar, Index Copernicus, J-Gate, Naviga (Softweco, Primo Central (ExLibris), ProQuest - Family Health, ProQuest - Health \& Medical Complete, ProQuest - Illustrata: Health Sciences, ProQuest Nursing \& Allied Health Source, Summon (Serials Solutions/ProQuest, TDOne (TDNet), Ulrich's Periodicals Directory/ ulrichsweb, WorldCat (OCLC)

The work was supported from the European Regional Development Fund-Project "Application of Modern Technologies in Medicine and Industry" (No. CZ.02.1.01/0.0/0.0/17 048/0007280)

Authors have declared that no competing interest exists.

Václav Beránek; phone: +420 737480136; e-mail: vberanek@kaz.zcu.cz

This is an open access article distributed under the terms of the Creative Commons Attribution-Non-Commercial-NoDerivatives 4.0 International (https://creativecommons.org/licenses/by-nc-nd/4.0/), which permits use, distribution and reproduction in any medium, provided the original work is properly cited, the use is non-commercial and is otherwise in compliance with the license. 


\section{INTRODUCTION}

Injuries are a serious problem from a medical, social and economic point of view. An injury means a bodily harm caused by a sudden and violent action of external forces. Injuries fall into the category of the most serious events that permanently change the health condition of a large share of the population, increasing the number of premature deaths and leading to significant financial losses for the society [1].

Child injuries are a particularly serious problem, since they can significantly reduce the child's potential, which is at its peak at this age group [2]. Child injuries are the most common causes of death. In developed countries, they account for up to $40 \%$ of all deaths in children under the age of fourteen[3].

Injuries are preventable, which means that they can be prevented by adopting protective practices and safe behavior patterns introduced in prevention programs. Such practices must be based on an excellent knowledge of the environment in which injuries occur. Instructional materials for children and young adults must be designed to attract and engage. Today, it is common to use various forms of presentation, such as pictures, stories or games. Nevertheless, newly-designed prevention programs are constantly introducing new elements and interesting innovations.

According to the World Health Organization (WHO), more than 5 million people worldwide die each year as a result of an accident. In the European region, 550,000 people die each year as a result of violence and accidental injuries, representing $6.1 \%$ of all deaths [4]. Injuries are considered to be the biggest health problem, especially in childhood, since the most common cause of death of children aged 1-14 is an injury or poisoning [5]. The differences between countries are considerable, mostly influenced by the level of care in accident prevention. In developed countries, injuries account for more than $40 \%$ of deaths in children aged 0-14. In the 35 member states of the Organization for Economic Co-operation and Development (OECD), 20,000 children die every year; in developing countries, the number is about 1 million. In the last 25 years, the proportion of deaths due to accidents has increased from $25 \%$ to $37 \%$.

Worldwide, the highest and at the same time the most significant accident rate is associated with transport. Traffic accidents account for up to $41 \%$ of all deaths due to injuries in children under 14 years of age. This is followed by drowning (15\%), intentional injuries (14\%), burns (7\%) and others.

Sweden, the Netherlands and the United Kingdom are the countries that report the lowest accident rate for children and also the lowest mortality rate in children under 14 years of age due to injuries. The percentage of child mortality due to injuries did not exceed $4.7 \%$ [6]. This summary and data analysis is missing in the Czech population. Therefore, the main aim of this study was to describe school accidents in the Czech Republic from 2008 to 2019. Special attention was paid to the fragmentation and description of the highest rate of accidents by educational level, age group, regions, school activity and the most frequent types of injuries. Future trends were estimated although it is expected that they will be strongly affected by the current COVID-19 pandemic.

\section{MATERIAL AND METHODS}

Various resources have been used to obtain data on injuries for the Czech Republic and in Czech schools. One of the main sources were the annual reports of the Czech School Inspectorate (CSI) from 2007 to 2017. Other valuable sources on injuries in children and young people were methodological guidelines, documents, reports and strategies 
of the Ministry of Health of the Czech Republic (MZCR) and the Ministry of Education, Youth and Sports of the Czech Republic (MSMT): Health 2020 National Strategy for the Protection and Promotion of Health and Disease Prevention, Report on the Health of the Population of the Czech Republic, Ensuring the Safety and Health Protection of Children, Pupils and Students in Schools and School Facilities and the National Action Plan for the Prevention of Child Injuries 2007-2017 and from specialized literature [7].

The collected data was summarized in terms of the absolute number of reported accidents per year and the corresponding total number of students. All data manipulations and post-processing was done in Microsoft Excel 2016. The data was fragmented according to the level as follows: kindergarten (KG), primary school (PS), high school (HS) and high professional school (HPS). Linear regression was done providing trend estimate in terms of trend line slope. The injury index was assessed as a ratio between the number of injuries and the number of students in percentage. The difference in the number of reported school accidents compared to 2007/2008 was assessed to show the evolution in the number of injuries. It is the number of reported school accidents in a given year minus the number of reported school accidents in 2007/2008. Finally, year-on-year change in the number of reported school accidents was evaluated. It is the number of reported school accidents in a given year minus the number of reported school accidents in the previous year.

\section{RESULTS}

With the child mortality rate of $8.5 \%$, the Czech Republic, together with Mexico and Portugal, is one of the countries with the highest child mortality rate [6]. Injuries are the most serious events permanently changing the health condition of the Czech population [8]. They come third as causes of death in general, and first in the age group of children and young adults. In the Czech Republic, 26,500 children are hospitalized for an accident, and 445,000 children under the age of fourteen are treated on an outpatient basis [3].

\section{THE MOST COMMON CAUSES OF INJURIES}

Insufficient supervision by adults is the most common cause of an injury, but even more importantly, it is the lack of knowledge on the part of children regarding how to avoid the risk of an injury. In addition to road accidents, these are mostly accidents due to falls and burns [9] For the period between 2009 and 2015, the National Register of Childhood Injuries lists falls or stumbles (19\%) and hitting or kicking by another person (13\%) to be the most common reasons for an accident; however, interventions with another object $(6 \%)$ and other causes of falls are also mentioned, such as missteps, jumps, etc. [10].

\section{THE MOST COMMON PLACES OF INJURIES}

The most serious accidents occur in traffic, but the most common place of injury for children is the home and school [3]. According to statistics, $26 \%$ of all reported accidents from the beginning to the end of compulsory school attendance are registered in the school environment [11]. Zvadová [12] adds that school accidents make up 20 to $40 \%$ of all accidents between 6 and 14 years of age.

\section{SPECIFICS OF SCHOOL INJURIES}

The National Action Plan for the Prevention of Child Injuries [6] identifies school accidents as a significant group of injuries that occur during education in schools, in school facilities, or in the provision of school services and related activities. Thanks to the clearly defined conditions for the registration and reporting of accidents imposed on school directors by the Methodological Instruction of the Ministry of Education, Youth and Sports [13], it is possible to compare data on reported school accidents over the past 10 years very accurately. Schools that have some specific focus, for example teaching specialized physical exercises, may tend to have a higher number of accident reports, where the 
physical actions of some martial arts are associated with a potential risk of injury [14]. For this reason, it is important to monitor accident data within the central system.

Injuries to children are registered not only by the CSI, but also by the Ministry of Health through the Institute of Health Information and Statistics of the Czech Republic. However, the statistics of this office are based only on reports from medical doctors, and they typically do not examine where and how the accident actually occurred. The doctor only enters into the records the information provided by the person accompanying the injured child.

\section{SCHOOL ACCIDENT STATISTICS FROM 2008 TO 2019}

Kindergartens, primary schools, secondary schools, colleges and other school facilities reported a total of 31,000 school accidents in the school year 2006/2007. Until the school year 2014/2015, the number of reported accidents did not exceed 37,000. Moreover, it was lower in some years. For example, in the school year 2012/2013, the number of reported injuries was only 29,000. The number of reported accidents has increased over the last five years (Table 1). The reason for this trend of an increasing number of reported injuries may be declining movement skills of children and pupils, and also a growing tendency of these age groups to engage in riskier activities [15].

Table 1. General overview of reported school accidents and number of students

\begin{tabular}{|c|c|c|c|c|c|c|c|c|c|c|c|}
\hline \multirow{2}{*}{$\begin{array}{l}\text { School } \\
\text { year }\end{array}$} & \multicolumn{7}{|c|}{ NUMBER OF SCHOOL ACCIDENTS REPORTED } & \multicolumn{4}{|c|}{ NUMBER OF STUDENTS } \\
\hline & Total* & Total+ & KG & PS & HS & HPS & Other & Total & KG & PS & HS \\
\hline $2007 / 2008$ & 33488 & 33488 & 679 & 22759 & 9771 & 279 & & 1752067 & 291194 & 888000 & 572873 \\
\hline $2008 / 2009$ & 31456 & 30714 & 698 & 20530 & 9288 & 198 & & 1728108 & 301620 & 858627 & 567861 \\
\hline $2010 / 2011$ & 31890 & 31890 & 1220 & 17831 & 12839 & & & 1695998 & 328612 & 830908 & 536478 \\
\hline $2011 / 2012$ & 36626 & 36626 & 1036 & 24648 & 10228 & 714 & & 1683094 & 342521 & 835796 & 504777 \\
\hline $2012 / 2013$ & 29191 & 29191 & 901 & 19748 & 8047 & 495 & & 1677504 & 354340 & 848755 & 474409 \\
\hline 2016/2017 & 43177 & 43177 & 1635 & 26832 & 11048 & 38 & 3624 & 1738794 & 362653 & 947497 & 428644 \\
\hline $2017 / 2018$ & 44572 & 44572 & 1657 & 27994 & 11083 & 49 & 3789 & 1755789 & 362756 & 967717 & 425316 \\
\hline 2018/2019 & 45726 & 45726 & 1697 & 28945 & 11245 & 47 & 3792 & 1771281 & 363776 & 982878 & 424627 \\
\hline
\end{tabular}

With respect to the stated values of school accidents, it is necessary to take into consideration that any increase can be caused both by an actual increase of the observed phenomenon and also by a more accurate reporting of this phenomenon [16]. As stated in the last CSI annual report for the school year 2018/2019, teachers are becoming increasingly more meticulous in reporting minor incidents for which they would not have previously assumed the possibility of compensation. The number of accidents according to individual educational levels from the data of the Czech Statistical Office [17] in total corresponds to the reported number of accidents according to the Annual Reports of the Czech School Inspectorate, except for the school years 2008/2009 and 2013/2014 (Table 1 ). The presumed cause may be a change in the methodology of data collection and also the unavailability of data on accidents for individual educational levels for specific school years (school years 2006/2007, 2013/2014, and 2014/2015). 
The reported school injuries have an increasing tendency especially for the primary school level (Fig. 1). Trend line slope for the total number of injuries was 986 injuries per year with the coefficient of determination $\mathrm{R} 2=0.7058$. It was 98, 783 and 104 injuries per year for KG, PS and HS, respectively, with $\mathrm{R}^{2}=0.8983,0.6527$ and 0.1035 .

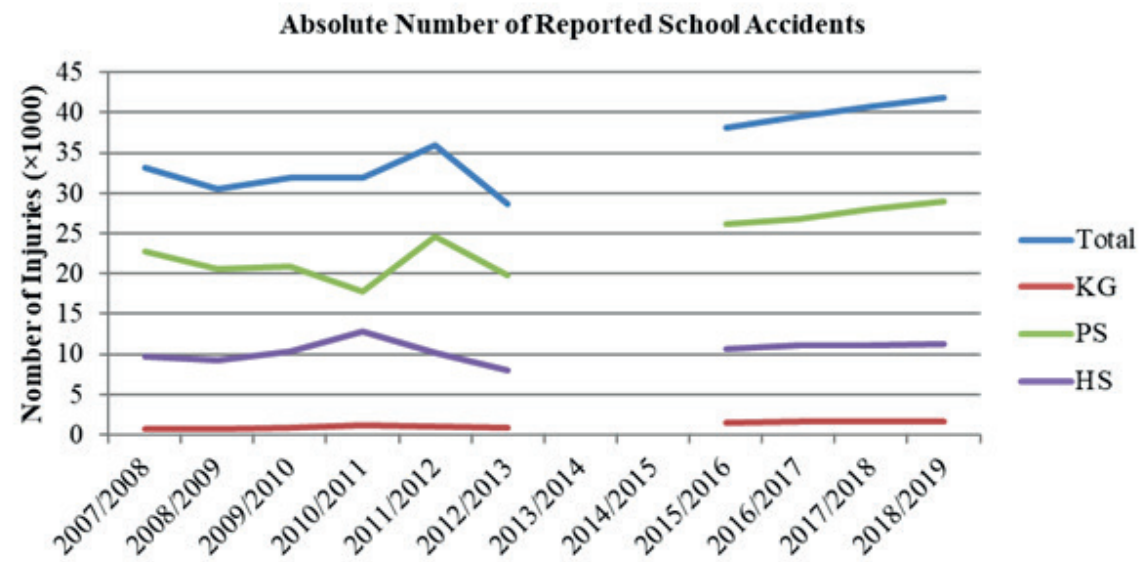

Fig. 1. General overview of reported school accidents

(KG - kindergarten, PS - primary school, HS - high school)

The increasing trend is also confirmed by the Injury Index (Table 2) which remains under $3 \%$, i.e. less than $3 \%$ of the students experience an injury related to the reported school accident. This result is even more pronounced when expressed in terms of the difference in the number of accidents with respect to 2007/2008 (Fig. 2).

Table 2. Injury index (No injuries / No students $\times 100(\%)$ )

\begin{tabular}{ccccc}
\hline School year & Total & KG & PS & HS \\
\hline $2007 / 2008$ & 1.90 & 0.23 & 2.56 & 1.71 \\
$2008 / 2009$ & 1.77 & 0.23 & 2.39 & 1.64 \\
$2009 / 2010$ & 1.87 & 0.25 & 2.49 & 1.85 \\
$2010 / 2011$ & 1.88 & 0.37 & 2.15 & 2.39 \\
$2011 / 2012$ & 2.13 & 0.30 & 2.95 & 2.03 \\
$2012 / 2013$ & 1.71 & 0.25 & 2.33 & 1.70 \\
$2013 / 2014$ & & & 2.45 & \\
$2014 / 2015$ & & & & 2.46 \\
$2015 / 2016$ & 2.22 & 0.39 & 2.84 & 2.58 \\
$2016 / 2017$ & 2.27 & 0.45 & 2.83 & 2.61 \\
$2017 / 2018$ & 2.32 & 0.46 & 2.89 & 2.65 \\
$2018 / 2019$ & 2.36 & 0.47 & 2.94 & \\
\hline KG - kindergarten, PS - primary school, HS - high school & & &
\end{tabular}

However, the year-on-year change in the total number of accidents seems to have a gradual declining trend at least in the last three years (Table 3, Fig. 3). 


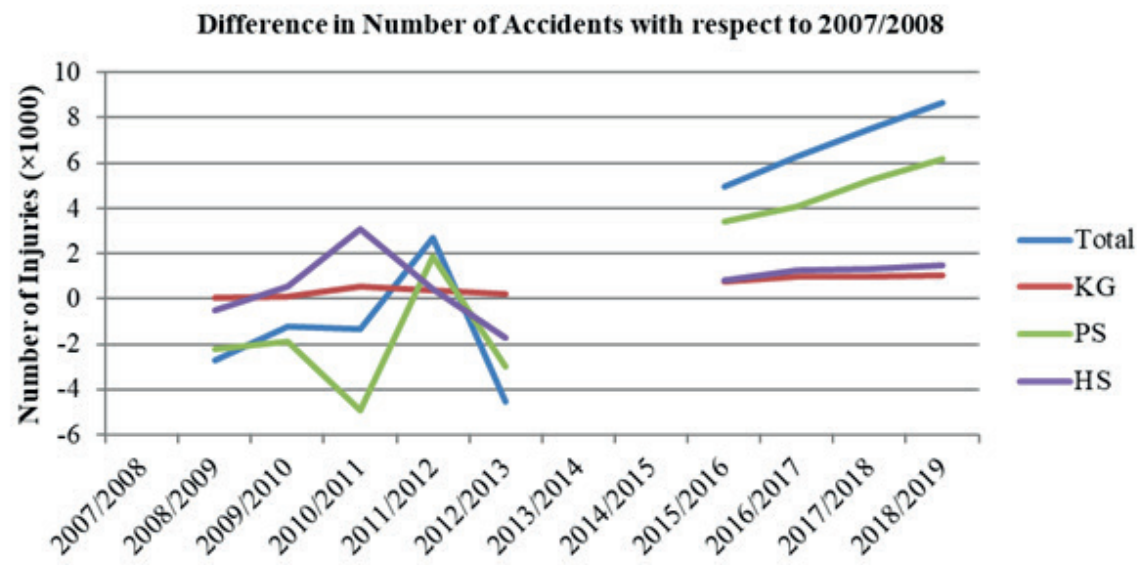

Fig. 2. Change in the number of reported school accidents compared to $2007 / 2008$. It is the number of reported school accidents in a given year minus the number of reported school accidents in 2007/2008

(KG - kindergarten, PS - primary school, HS - high school)

Table 3. Year-on-year change in the number of accidents. It is the number of reported school accidents in a given year minus the number of reported school accidents in the previous year

\begin{tabular}{ccccc}
\hline School year & Total & KG & PS & HS \\
\hline $2008 / 2009$ & -2693 & 19 & -2229 & -483 \\
$2009 / 2010$ & 1467 & 95 & 322 & 1050 \\
$2010 / 2011$ & -93 & 427 & -3021 & 2501 \\
$2011 / 2012$ & 4022 & -184 & 6817 & -2611 \\
$2012 / 2013$ & -7216 & -135 & -4900 & -2181 \\
$2013 / 2014$ & & & & \\
$2014 / 2015$ & & & & \\
$2015 / 2016$ & & & & \\
$2016 / 2017$ & 1337 & 214 & 687 & 436 \\
$2017 / 2018$ & 1219 & 22 & 1162 & 35 \\
$2018 / 2019$ & 1153 & 40 & 951 & 162 \\
\hline
\end{tabular}

KG - kindergarten, PS - primary school, HS - high school

Year-on-year Change in the Number of Accidents
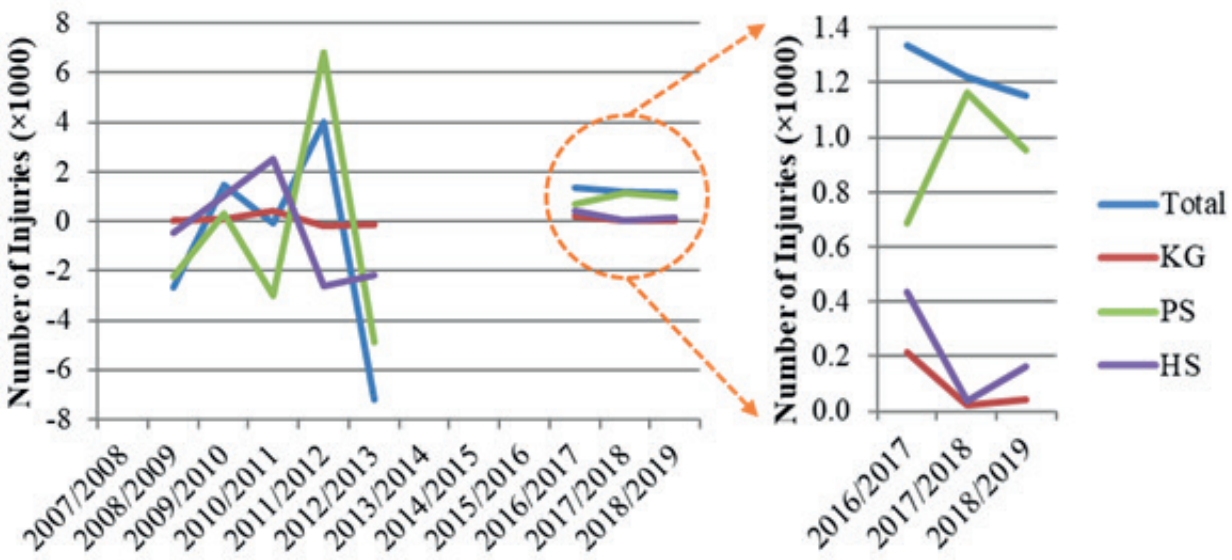

Fig. 3. Year-on-year change in the number of accidents with zoom on last three years. It is the number of reported school accidents in a given year minus the number of reported school accidents in the previous year 


\section{THE HIGHEST RATE OF ACCIDENTS BY EDUCATIONAL LEVEL}

Primary schools register the highest number of reported accidents every year. Since the school year 2007/2008, there have been between 18,000 and 29,000 reported accidents annually. For the school year $2018 / 2019$, the number of primary school accidents was 29,000 which represented $62 \%$ of the total number of reported accidents in the Czech Republic between 2018 and 2019 [15].

\section{THE HIGHEST RATE OF ACCIDENTS BY AGE GROUP}

Zvadová states that the age range of 11-12 years for girls and 12-13 years for boys is the most risky one due to the acceleration of growth in puberty and associated weight gain. For girls, 39\% of all accidents occur throughout the period around the age of 12 , and for boys, $37 \%$ of all accidents around the age of 13 . In the stated age range, an accident affects every fourth girl and every third boy. Injuries in boys are more frequent by $18 \%$ compared to girls. Overweight and obese children are four times more likely to be injured [12].

\section{THE HIGHEST RATE OF ACCIDENTS BY REGIONS}

Since 2008, the highest school accident rate has been reported by the Pardubice Region and the Vysočina Region. The lowest school accident rate is in Prague. Every year, Pilsen ranks 6th to 9th out of 14 monitored regions [15].

\section{THE HIGHEST RATE OF ACCIDENTS BY SCHOOL ACTIVITY}

The highest number of reported school accidents since 2008 comes from group activities within the subject of Physical Education. School breaks are second in terms of accident occurrence. The third place relates to individual activities in Physical Education and the fourth place to standard classes. To a lesser extent, accidents also occur during school trips or specific courses [15]. The National Register of Childhood Injuries states that $54 \%$ of accidents occur directly at school and during sports events, on school playgrounds and other premises [10].

\section{THE MOST FREQUENT TYPES OF INJURIES}

According to the National Register of Childhood Injuries, the most common type of injury between 2009 and 2015 was a fracture, accounting for almost 50\%. Concussion, contusion and various forms of joint injuries were among other frequent types [10]. Injuries that occur at school are most often related to the upper limb (50\%), followed by the lower limbs, head, neck or chest area [15]. The International Classification of Diseases contributes to the detailed description of specific injuries. It aims to ensure that diseases, injuries, causes of death and other relevant health problems are reported and classified in the same way in all WHO Member States [18].

\section{Prevention}

The influences of family and school are the key factors in the prevention of injuries in children. It is the school education system that is the second most important place where children and young people can be influenced in a long-term and effective way about how to handle the common risks of life. This is also confirmed by the motto of the methodological instruction of the MSMT for the School Preventive Program for Kindergartens and Primary Schools and School Facilities:

"The most effective and cheapest prevention is the healthy upbringing of children in the family and at school. Good education of children is also a program of prevention of individual health-damaging and life-degrading addictions and phenomena" [19].

The aim of this methodological instruction is to offer the school specific ways to become a place for safe and effective education. However, each school is unique and thus it must decide about the particular areas on which to focus in its preventive activities. 
Another important document is the National Strategy for the Primary Prevention of Risk Behavior of Children and Youth for the Period 2013-2018 [20], which focuses on prevention of the development of risks in the behavior of children and youth. These risks also include injuries during sports activities and in transport.

The document Methodological Guidelines for Ensuring the Safety and Health Protection of Children, Pupils and Students in Schools and School Facilities established by the MSMT [13] focuses on the safety of students. The school has to ensure the safety and health protection of students in education. Attention is paid to the responsibilities of students, their health conditions and requirements, supervision, protective equipment and specific school activities, such as swimming, ski training, etc.

\section{Preventive educational materials}

Based on methodological instructions and recommendations, a number of preventive materials focusing on injuries in children and young people have been created. Contracting authorities, sponsors or creators of the materials include individual regions, cities, state health institutes, health insurance companies, ministries or non-profit organizations. In the years 2007 to 2014, the Vysočina Region co-financed, in cooperation with the State Institute of Public Health in Prague several publications entitled: So That Nothing Happens (2014), Danger Lurks Everywhere (2013), Now I Know (2007). These workbooks and methodological worksheets incorporate pictorial material and focus on kindergarten and primary school children.

The mutual cooperation of the General Health Insurance Company, the Capital City of Prague and the non-profit organization called Childhood without Injuries resulted in a number of preventive educational materials in the pdf format, such as the documents "Home Security Audit", "Tips for Games, Activities and Worksheets", "Prevention of Risk Behavior", "First Aid" and others. The added value is linked to the innovative approach, which is aimed at children and young people and attempts to address them with artistic color elements, memory games, jigsaw puzzles, coloring books, etc. [17].

Between 2003 and 2010, a specially adapted ambulance travelled to the district towns of the Czech Republic, bringing teaching materials for schools, activities for children and information for their parents. The van from the project partner Mercedes Benz attracted the necessary attention and promoted associated activities such as press conferences, training for teachers and other events. A similar event was the mobile "Giant Kitchen" project, which focused on accidents at home. Here, too, a specially adapted car toured the schools and offered them experience and new information through an interestingly designed interior [12].

\section{CONCLUSION}

Injuries to children do not happen without a reason, they have their causes. An important role of preventive measures is to anticipate and avoid risky situations. It is necessary to look for new innovative forms of presentation of prevention programs aimed at children and youth. A special role is played by the school, especially the primary school, where the largest number of accidents occur every year. On the other hand, while the total number of reported school accidents has been increasing every year since $2007 / 2008$, there is a declining year-on-year trend. This may suggest that prevention programs work and have a positive impact.

In today's world, which is literally full of information stimuli, the attention of children makes ever-increasing demands on the attractiveness of such programs. Properly targeted and timed prevention programs for children and young people can help them to avoid their injuries. It is expected that the current COVID-19 pandemic will have a tremendous effect on data collected and reported in near future considering strong school attendance 
restrictions in the Czech Republic. A close follow-up and analysis of data and prevention programs will be needed even more with special focus on mental health possibly negatively affected by the pandemic-related restrictions.

\section{REFERENCES}

[1] Kasalová Daňková, Š. Aktuální informace Ústavu zdravotnických informací a statistiky České republiky. Vývoj úrazovosti dětí do roku 2006. [Current information of the Institute of Health Information and Statistics of the Czech Republic. Development of children's injuries until 2006]. 2006 [retrieved from http://www.uzis.cz/system/files/05 08. pdf]. Czech.

[2] Injuries and prevention. 2010 [retrieved from http://193.225.50.35/dokumentum/2009/ANG_0602.pdf].

[3] WHO. European inventory of national policies for the prevention of violence and injuries. 2014 [retrived from http:// www.euro.who.int/en/health-topics/disease-prevention/violence-and-injuries/violence-and-injuries].

[4] Výroční zprávy Česká školní inspekce. 2007-2019 [Annual reports of the Czech School Inspectorate]. [retrieved from http://www.csicr.cz/cz/DOKUMENTY/Vyrocni-zpravy/]. Czech.

[5] Grivna M, et al. Dětské úrazy a možnosti jejich prevence [Children's injuries and possibilities of their prevention] 1st ed. Prague: Centrum úrazové prevence UK 2. LF a FN Motol, 2003. Czech.

[6] Národní strategie primární prevence rizikového chování dětí a mládeže na období 2013-2018 [National strategy of primary prevention of risky behavior of children and youth for the period 2013-2018]. MŠMT. Prague, 2018. [retrived from http://www.msmt.cz/file/28077?highlightWords=\%C5\%A0koln\%C3\%AD+preventivn\%C3\%AD+program]. Czech.

[7] ZDRAVÍ 2020, Národní strategie ochrany a podpory zdraví a prevence nemocí. [National strategies for health protection and promotion and disease prevention] 1st ed. Prague: Ministerstvo zdravotnictví České republiky-Geoprint, 2014. Czech.

[8] Doubrava L. Více úrazů žáků, větší právní komplikace pro školy [More injuries to students, more legal complications for schools]. Učitelské noviny, 2016;19:4-6 [retrieved from http://www.vychovakezdravi.cz/clanky/prevence-urazu/ tematicke-zajimavosti.html]. Czech.

[9] Zajištění bezpečnosti a ochrany zdraví dětí, žáků a studentů ve školách a školskýchzařízeních zřizovaných Ministerstvem školství, mládeže a tělovýchovy [Ensuring the safety and health protection of children, pupils and students in schools and school facilities established by the Ministry of Education, Youth and Sports]. MŠMT, 2005 [retrieved from http://www.msmt.cz/dokumenty/metodicky-pokyn-k-zajisteni-bezpecnosti-a-ochrany-zdravi-deti-zaku-a-studentuve-skolach-a-skolskych-zarizenich-zrizovanych-ministerstvem-skolstvi-mladeze-a-telovychovy]. Czech.

[10] Dětství bez úrazů. 1996 -2016 [Childhood without injuries. 1996 - 2016]. 2018 [retrieved from http://detstvibezurazu.cz/prevence-detskych-urazu-materialy/]. Czech

[11] Národní akční plán prevence dětských úrazů na léta 2007-2017 [National Action Plan for the Prevention of Child Injuries for the years 2007-2017]. 2007 [retrieved from http://www.mzcr.cz/Odbornik/dokumenty/narodni-akcni-plan-prevence-detskych-urazu_2049_1009_3.html].

[12] Tošovský V. Chraňme děti před úrazy: prevence úrazů dětí a mládeže [Protecting children from injuries: prevention of injuries to children and young people]. Prague: Alfa-Omega, 2006. Czech.

[13] MKN-10. Mezinárodní statistická klasifikace nemocí a přidružených zdravotních problémů. Aktualizovaná druhá verze k 1.1. 2009 [International Statistical Classification of Diseases and Related Health problems. Updated second version to 1.1. 2009]. Prague: Bomton Agency, 2008. Czech.

[14] Beranek V, Votapek P, Stastny P. Force and velocity of impact during upper limb strikes in combat sports: a systematic review and meta-analysis, Sports Biomechanics. 2020. DOI: 10.1080/14763141.2020.1778075

[15] Výsledky studie vývoje a úrazovosti u školních dětí. Zvadová [Results of a study of development and injuries in school children]. 2013 [retrieved from http://www.khsova.cz/docs/01_tisk/files/clanky_urazy_deti_2013.pdf].

[16] Děti bez úrazu. Preventivní buňka CDT FN Brno [Children without injuries. Preventive cell CDT FN Brno]. 2015 [retrieved from http://www.detibezurazu.cz/prevence-urazu/]. Czech

[17] Český statistický úřad. Školy a školská zařízení [Czech Statistical Office. Schools and school facilities]. Prague; 2020 [retrieved from https://www.czso.cz/csu/czso/b-zakladni-vzdelavani-celkem]. Czech

[18] Kodl M. Zpráva o zdraví obyvatel České republiky [Report on the health of the population of the Czech Republic]. Prague: Ministerstvo zdravotnictví České republiky-Geoprint, 2014. Czech.

[19] Tisková zpráva [Press Release]. MZCR, 2015 [retrieved from http://www.mzcr.cz/dokumenty/nejvice-detskych-urazuzaznamenavame-v-letecasteji-se-zrani-chlapci-_10430_3237_1.html]. Czech.

[20] Školní preventivní program pro mateřské a základní školy a školská zařízení [School prevention program for kindergartens and primary schools and school facilities]. MŠMT, 2010. [retrieved from http://www.google.cz/search?h] $=\mathrm{cs} \&$ source $=\mathrm{hp} \& \mathrm{q}=\% 9 \mathrm{Akoln} \% \mathrm{ED}+$ preventivn $\% \mathrm{ED}+$ program + site $\% 3 \mathrm{Amsmt} . \mathrm{cz} \& \mathrm{aq}=\mathrm{f} \& \mathrm{aqi}=\&$ aql $=\&$ \&oq $=\& g s \_r f a-$ $\mathrm{i}=\& \mathrm{cad}=\mathrm{h}]$. Czech. 